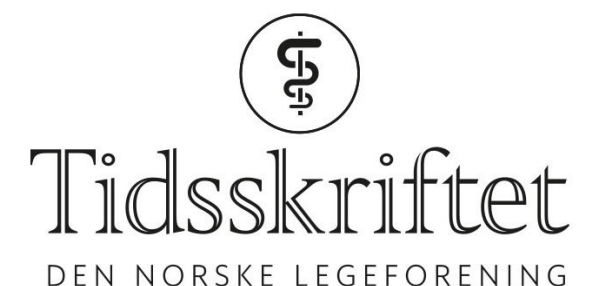

DEN NORSKE LEGEFORENING

\title{
Statistisk styrke og dikotomisering
}

KOMMENTAR

\section{JOAR ØVERAAS HALVORSEN}

E-post: joarhalvorsen@gmail.com

Joar Øveraas Halvorsen er psykolog og postdoktor.

Ingen oppgitte interessekonflikter.

Eva Skovlund har skrevet nok en god og informativ artikkel i Tidsskriftets statistikkspalte (1). Skovlund viser at dikotomisering av kontinuerlige variabler kan ha en rekke uheldige konsekvenser, hvor en av de viktigste er tap av statistisk styrke. Dette er en velkjent problemstilling (2). Skovlund påpeker at lav eller dårlig statistisk styrke er en risikofaktor for falske-negative forskningsfunn (type II-feil), og at man feilaktig konkluderer at det ikke er en statistisk signifikant forskjell mellom for eksempel to behandlingsbetingelser. Skovlund unnlater imidlertid å nevne at lav eller dårlig statistisk styrke faktisk også er en risikofaktor for falske-positive forskningsfunn (type I-feil) (3-5), og overestimerte effektstørrelser $(6,7)$. Derfor kan dikotomisering av variabler med påfølgende tap av statistisk styrke, kanskje noe paradoksalt, være en risikofaktor for både type I- og type II-feil samt overestimering av effektstørrelser. Det er viktig at klinikere er klar over av studier med lav eller dårlig statistisk styrke risikerer både å feilaktig beholde og forkaste nullhypotesen. Det vil være uheldig om klinikere har et inntrykk av at lav statistisk styrke kun er en risikofaktor for falske-negative forskningsfunn, og at statistisk signifikante funn fra studier med lav statistisk styrke er til å stole på. Studier med lav statistisk styrke bør tolkes særlig varsomt og kritisk - uavhengig av om resultatene er statistisk signifikante eller ei.

\section{LITTERATUR:}

1. Skovlund E. Dikotomisering av målevariabler - hva er prisen? Tidsskr Nor Legeforen 2017; 137: 1904 .

2. Tabachnick BG, Fidell LS. Using multivariate statistics (5. utg.). Boston, MA: Allyn \& Bacon/Pearson Education, 2007.

3. Button KS, Ioannidis JPA, Mokrysz C et al. Power failure: why small sample size undermines the reliability of neuroscience. Nat Rev Neurosci 2013; 14:365 - 76. [PubMed][CrossRef]

4. Christley RM. Power and error: increased risk of false positive results in underpowered studies. Open Epidemiol J 2010; 3: 16 - 9. [CrossRef]

5. Ingre M. Why small low-powered studies are worse than large high-powered studies and how to protect against «trivial» findings in research: comment on Friston (2012). Neuroimage 2013; 81: 496 - 8. [PubMed][CrossRef]

6. Ioannidis JPA. Why most discovered true associations are inflated. Epidemiology 2008; 19: 640 - 8. [PubMed][CrossRef] 
7. Yarkoni T. Big correlations in little studies: inflated fMRI correlations reflect low statistical powercommentary on Vul et al. (2009). Perspect Psychol Sci 20o9; 4: 294 - 8. [PubMed][CrossRef]

Publisert: 16. mars 2018. Tidsskr Nor Legeforen. DOI: 10.4045/tidsskr.18.0189

(C) Tidsskrift for Den norske legeforening 2020. Lastet ned fra tidsskriftet.no 